\title{
Insecticidal potential of physic nut fruits of different stages of maturation on Myzus persicae (Hemiptera: Aphididae)
}

\author{
Potencial insecticida de frutos de piñón manso en diferentes etapas \\ de maduración sobre Myzus persicae (Hemiptera: Aphididae)
}

\author{
Anderson Mathias Holtz ${ }^{1}$, Jeanne Scardini Marinho-Prado ${ }^{*}$, Tatiane Pereira Cofler ${ }^{1}$, \\ Ana Beatriz Mamedes Piffer ${ }^{1}$, Mylena da Silva Gomes ${ }^{1}$, Vergilio Borghi Neto ${ }^{1}$
}

\begin{abstract}
Jatropha curcas L. (Euphorbiaceae) is a plant species widely present in tropical and subtropical regions that have been studied mainly for its potential for biofuel production; it is also a plant known for its toxic substances. To explore its use as an insecticide, we studied the effect of the seed extract from green fruit and the seed oils from the mature and dried fruit of $J$. curcas on the green aphid Myzus persicae (Hemiptera: Aphididae). Seven concentrations of extracts and oils of different maturation stages of fruits were used and sprayed with the Potter Spray Tower on cabbage leaves containing 10 individuals of $M$. persicae. Ten repetitions for each concentration were carried out at each stage of maturation (green, ripe, and dry), and the evaluation of the mortality of individuals occurred for a period of 72 hours. The maturation stage of J. curcas, as well as the concentration and time after the application, influenced the mortality of $M$. persicae. The best results were obtained $48 \mathrm{~h}$ after applying the dried fruit oil at $2.5 \%$ and 72 hours after the application of dry and ripe fruit oil at $2.5 \%$.
\end{abstract}

Keywords: alternative control, mortality, cabbage aphid, Jatropha curcas.

\section{RESUMEN}

La Jatropha curcas L. (Euphorbiaceae) es una especie vegetal, ampliamente presente en regiones tropicales y subtropicales, que ha sido estudiada principalmente por su potencial para la producción de biocombustibles. Pero también es una planta conocida por sus sustancias tóxicas. Para verificar su uso como insecticida, estudiamos el efecto del extracto de semillas de frutos verdes y aceites de semillas de frutos maduros y secos de J. curcas sobre el pulgón verde Myzus persicae (Hemiptera: Aphididae). Siete soluciones, en diferentes concentraciones de los extractos y aceites, fueron utilizadas y pulverizadas con la Torre de Pulverización de Potter en hojas de repollo, con 10 individuos de M. persicae cada una. Se realizaron diez repeticiones para cada concentración en cada etapa de maduración (verde, maduro y seco) y la evaluación de la mortalidad de los individuos ocurrió en un período de 72 horas. El estadio de maduración de J. curcas, la concentración y el tiempo después de la aplicación influyeron la mortalidad de M. persicae. Los mejores resultados se obtuvieron 48 horas después de la aplicación del aceite de frutos secos a 2,5\%, y 72 horas después del aceite de los frutos secos y maduros a 2,5\%.

Palabras clave: control alternativo, mortalidad, pulgón verde, Jatropha curcas.

\section{Introduction}

The cabbage aphid, Myzus persicae (Sulzer 1776) (Hemiptera: Aphididae), is widely present in temperate and subtropical regions of the world, and most of its host plants belong to the Brassicaceae family (Ellis y Singh, 1993). In Brazil, this aphid species is considered an important pest of cabbage, and it causes damages sucking the sap and introducing toxins into the plants' vascular system. Moreover, they are responsible for transmitting viruses and shrinkage of leaves, impairing plant development (Gallo et al., 2002).

Among the methods used for aphid control in agriculture, the chemical method is still the most usual. However, the intensive use of chemicals -especially those not registered for a specific pestmay cause the resurgence of the target pest, as well as the emergence of new pests, since most of these

\footnotetext{
1 Instituto Federal do Espírito Santo, Campus Itapina, Colatina, Espírito Santo, Brazil.

2 Embrapa Meio Ambiente, Jaguariúna, São Paulo, Brazil.

* Corresponding author: jeanne.marinho@embrapa.br
} 
products used has a broad biological spectrum and remain in the environment, harming thus the health of consumers and professionals involved in the production (Brito et al., 2004). Intending to find alternatives to chemicals, which has a high socioeconomic cost, research on the use of extracts and substances of plants has been conducted for pest control.

Jatropha curcas L. (Euphorbiaceae) is a plant species common in tropical and subtropical areas and has been studied mainly for its potential to produce biofuels (Gubitz et al., 1999; Gonzáles, 2016). However, many biologically active substances have been isolated and characterized from different parts of the plant, and its mechanisms of action have been studied for many applications - from its use in traditional medicine to molluscicide, insecticides, and fungicides properties (Gubitz et al., 1999; Sabandar et al., 2013; Ukpai et al., 2017; Roy et al., 2018). It is known that various compounds are responsible for the toxicity of J. curcas plants; these compounds can be found all over the plant but are most abundant in the seeds (Gubitz et al., 1999). The toxicity of J. curcas seed has been mainly attributed to the presence of diterpenes (phorbol esters; PEs), ribosome-inactivating proteins (RIP; curcin), saponins, trypsin inhibitor, protease inhibitors, curcain, jatrophidin, phytates, alkaloids, lectins, lignans, tannins, flavonoids, phenols, latex and cyclic peptides (Maghuly y Laimer, 2013; Ukpai et al., 2017).

Many studies have proven the insecticide and deterrent potential of $J$. curcas on insects through the use of extracts, oils, or pure isolated compounds from parts of the plant (Adebowale y Adedire, 2006; Devappa et al., 2012; Silva et al., 2012, Ukpai et al., 2017). The chemical composition and the number of metabolites in different plant parts can vary due to various environmental factors, such as temperature, humidity, and precipitation (Ermel et al., 1987; Sousa et al., 2009; Silva et al., 2012). Moreover, in the case of oils and seed extracts, the quantity and quality of chemicals may vary due to the stage of fruit maturation (Ermel et al., 1987).

Thus, due to the availability of J. curcas plants, the importance related to the potential use of their oil for biodiesel production, as well as the benefits that this plant can offer as an alternative to synthetic pesticides, this study evaluated the effect of J. curcas seeds extracted in different stages of maturation on the mortality of M. persicae in cabbage.

\section{Materials and Methods}

The experiment was conducted at the Federal Institute of Education, Science and Technology of Espírito Santo - Campus Itapina (IFES - Campus Itapina, Brazil) in climate chambers $\left(25 \pm 1^{\circ} \mathrm{C}\right.$, $70 \pm 10 \%$ of relative humidity and photophase of 12 hours). Individuals of M. persicae used for tests were obtained from insect rearing in greenhouses and cabbage fed (Brassicae oleracea var. Acephala) without any phytosanitary treatment.

\section{Extract and oil}

J. curcas seeds were collected from green, ripe, and dried fruits in the experimental area of IFES - Campus Itapina. After this procedure, seeds of green fruits were placed to dry in an oven of forced air circulation at a temperature of $40{ }^{\circ} \mathrm{C}$ for 72 hours. After this process, seeds of green fruits were ground with the aid of a cutting mill to obtain a fine powder. The powder obtained was diluted in concentrations used in the test with distilled water, and the solution was stirred in a magnetic stirrer for four hours at ambient temperature. The material rested about $20 \mathrm{~min}$ for decanting, and the supernatant was filtered with a funnel with cotton. The oil from seeds of ripe and dried fruits was extracted by cold pressing. For the tests, concentrations of 0.0, 0.5, 1.0, $1.5,2.0,2.5$, and $3.0 \%$ of extracts from green fruits (weight/volume) and oil of ripe and dried seeds of $J$. curcas (volume/volume) were used. For the oil dilution and application and the aqueous extract, distilled water with adhesive spreader Tween ${ }^{\circledR} 80$ $(0.05 \%)$ was used.

\section{Bioassay}

Each of the solutions containing different contents of the green seed extract and oil of ripe and dried seeds of J. curcas was applied on ten $M$. persicae individuals, kept on disks ( $8 \mathrm{~cm}$ diameter $)$ of cabbage leaves (B. oleracea var. Acephala).

The foliar disks were placed on Petri dishes $(10.0 \times 1.2 \mathrm{~cm})$ on filter paper which was moistened with distilled water daily to maintain the leaf turgor. The sample board consisted of discs sprayed with a solution containing distilled water and an adhesive spreader. The solutions were applied on the foliar disks with a Potter spray tower with a pressure of $15 \mathrm{Lb}_{\mathrm{p} p l^{2}}$ and volume of $6 \mathrm{~mL}$ per repetition. 
The experiment was conducted with factorial $3 \mathrm{x}$ $7 \times 10$ ( 3 stages of fruit maturation, 7 concentrations, and 10 repetitions), been each Petri dish one repetition. The individuals' mortality was evaluated 24,48 , and $72 \mathrm{~h}$ after the spraying. The mortality data were transformed into arc sine of $\sqrt{ }(\mathrm{x} / 100)$ and submitted to the analysis of variance, and the means were compared by the Tukey's test at $5 \%$ of probability. To see the effect of the concentration of $J$. curcas oil and extract over M. persicae in each time, the data were submitted to regression analysis, at $5 \%$ of significance.

\section{Results}

The J.curcas maturation stage influenced the mortality of cabbage aphids (M. persicae) according to the concentration and time after applying dried or ripe seeds oil or green seeds extract. Only the concentrations of 0.0 and $2.0 \%$ of extract and fruit oil at any maturation stage have not affected $M$. persicae mortality in any of the evaluated periods (Table 1).

Twenty-four hours after the treatments, the dried J. curcas oil presented the highest mortality rates when used at the highest concentrations tested, 2.5 and $3.0 \%$ (mortality of 32 and $37 \%$ of the individuals, respectively). The dried fruit also caused the highest mortality of aphids 48 hours after the application - concentrations of 1.5, 2.5 and $3.0 \%$ (55, 61 and $61 \%$, respectively); and 72 hours after the oil application at $0.5 \%, 1.0 \%$ and $1.5 \%$ (56\%, 56\% and 60\% respectively). In the evaluation performed $72 \mathrm{~h}$ after the spraying, the two highest concentrations tested for the oils obtained from dried and ripe fruits $(2.5 \%$ and $3.0 \%)$ caused a similar mortality rate in the population of aphids tested. This result was significantly higher than the presented for the same concentrations of the extract of green fruit (mortality of $32 \%$ and $44 \%$, respectively) (Table 1).

Increased mortality of cabbage aphids was directly proportional to the increased concentration of the tested extracts and oils -data adjusted to a linear model $\left(\mathrm{R}^{2}>80.0 \%\right)$-, excepting the green fruit extract evaluated after the first 24 hours (Figure 1).

\section{Discussion}

The efficacy of $J$. curcas for insect control is probably due to the presence of secondary compounds known for their protection against pest attack (Cardoso et al., 2001; Cavalcanti et al., 2005; Schoonhoven et al., 2005; Ukpai et al., 2017). Selase y Getu (2009) evaluated the capability of the powder of J. curcas seed and leaves and of other plants to control Zabrotes subfasciatus and observed a mortality rate above $90 \%$ after 96 hours on bean seeds treated with J. curcas powder at the concentration of $15 \mathrm{~g} / 150 \mathrm{~g}$ (powder weight/mass of seeds).

Adebowale and Adedire (2006) investigated the chemical composition of J. curcas seeds and identified, in the unsaponifiable fraction of the oil, ten steroids, and thirteen triterpenic alcohols. The insecticidal activity was observed on eggs of the Callosobruchus maculates beetle, and J. curcas oil was considered by the authors as a promising substance for pest control of legumes (Adebowale y Adedire, 2006). Based on a comparative performance of $J$. curcas oil, garlic oil, and three synthetic acaricides against the red spider mite Oligonychus coffeae, the physic nuts oil formulation demonstrated the second-highest toxicity to eggs and adults, besides repellence and eggs deterrence comparable to that of the synthetic acaricides (Roy et al., 2018). The phytochemical analysis of the J. curcas dust showed a high level of alkaloids and tannins, besides a low level of flavonoids, saponins, and phenols (Ukpai et al., 2017). This same seed dust reduced significantly the population of Sitophilus zeamais evaluated (Ukpai et al., 2017).

J. curcas seeds are toxic to humans and animals and, for this reason, their nutrients consumption is not possible (Haas et al., 2002). Among all secondary compounds presents in the seeds, according to Stirpe et al. (1976), the toxicity of J. curcas can be attributed mainly to the presence of two components: one ribosome-inactive protein (curcin) and the diterpene esters. Curcin is similar to ricin, a toxic protein isolated from castorbean seeds (Ricinus communis) (Bashir et al., 1998; Darby et al., 2001). However, the main and most studied group which is considered responsible for the toxicity of physic nut seeds is diterpene esters called phorbol esters, which are present in relatively high concentrations in the Euphorbiaceae plants family to which J. curcas belongs (Haas et al., 2002).

In a study made by Makkar et al. (1998) with four varieties of $J$. curcas -two originally from Nicaragua, one from Nigeria, and one from Mexico-, the average seed weight, seed's percentage of fiber, and the quantity of raw protein in each species beyond 
Table 1. Mean mortality (\%) \pm SE (Standard Error) of Myzus persicae submitted to different concentrations of oil of seeds from dried and ripe fruits, and green fruit extract of Jatropha curcas: 24, 48 and 72 hours after spraying (HAS).

\begin{tabular}{|c|c|c|c|}
\hline HAS & $24 \mathrm{~h}$ & $48 \mathrm{~h}$ & $72 \mathrm{~h}$ \\
\hline Maturation stage/Concentration & & $0.0 \%$ & \\
\hline Dried & $0.0 \pm 0.0 \mathrm{Aa}$ & $2.0 \pm 2.0 \mathrm{Aa}$ & $7.0 \pm 2.4 \mathrm{Aa}$ \\
\hline Ripe & $6.0 \pm 2.0 \mathrm{Aa}$ & $9.0 \pm 0.0 \mathrm{Aa}$ & $11.0 \pm 2.4 \mathrm{Aa}$ \\
\hline \multirow[t]{2}{*}{ Green } & $5.0 \pm 2.0 \mathrm{Aa}$ & $8.0 \pm 0.0 \mathrm{Aa}$ & $11.0 \pm 2.4 \mathrm{Aa}$ \\
\hline & \multicolumn{3}{|c|}{$0.5 \%$} \\
\hline Dried & $8.0 \pm 2.4 \mathrm{Ba}$ & $19.0 \pm 2.0 \mathrm{Ba}$ & $56.0 \pm 3.2 \mathrm{Aa}$ \\
\hline Ripe & $6.0 \pm 2.0 \mathrm{Ba}$ & $9.0 \pm 2.0 \mathrm{Ba}$ & $21.0 \pm 2.0 \mathrm{Ab}$ \\
\hline \multirow[t]{2}{*}{ Green } & $9.0 \pm 2.0 \mathrm{Ba}$ & $20.0 \pm 0.0 \mathrm{Aba}$ & $22.0 \pm 2.4 \mathrm{Ab}$ \\
\hline & \multicolumn{3}{|c|}{$1.0 \%$} \\
\hline Dried & $4.0 \pm 4.0 \mathrm{Ca}$ & $18.0 \pm 3.7 \mathrm{Ba}$ & $56.0 \pm 2.4 \mathrm{Aa}$ \\
\hline Ripe & $10.0 \pm 2.4 \mathrm{Ba}$ & $22.0 \pm 2.0 \mathrm{Ba}$ & $40.0 \pm 2.0 \mathrm{Aab}$ \\
\hline \multirow[t]{2}{*}{ Green } & $7.0 \pm 2.0 \mathrm{Ba}$ & $14.0 \pm 0.0 \mathrm{Ba}$ & $36.0 \pm 2.4 \mathrm{Ab}$ \\
\hline & \multicolumn{3}{|c|}{$1.5 \%$} \\
\hline Dried & $20.0 \pm 3.7 \mathrm{Ba}$ & $55.0 \pm 4.5 \mathrm{Aa}$ & $60.0 \pm 2.0 \mathrm{Aa}$ \\
\hline Ripe & $16.0 \pm 2.4 \mathrm{Ba}$ & $23.0 \pm 0.0 \mathrm{ABb}$ & $40.0 \pm 0.0 \mathrm{Ab}$ \\
\hline \multirow[t]{2}{*}{ Green } & $12.0 \pm 2.0 \mathrm{Ba}$ & $19.0 \pm 0.0 \mathrm{Bb}$ & $36.0 \pm 2.4 \mathrm{Ab}$ \\
\hline & \multicolumn{3}{|c|}{$2.0 \%$} \\
\hline Dried & $25.0 \pm 2.0 \mathrm{Ba}$ & $50.0 \pm 2.0 \mathrm{Aa}$ & $58.0 \pm 0.0 \mathrm{Aa}$ \\
\hline Ripe & $17.0 \pm 2.0 \mathrm{Ba}$ & $42.0 \pm 2.5 \mathrm{Aa}$ & $51.0 \pm 2.5 \mathrm{Aa}$ \\
\hline \multirow[t]{2}{*}{ Green } & $15.0 \pm 2.0 \mathrm{Ba}$ & $38.0 \pm 0.0 \mathrm{Aa}$ & $46.0 \pm 2.5 \mathrm{Aa}$ \\
\hline & \multicolumn{3}{|c|}{$2.5 \%$} \\
\hline Dried & $32.0 \pm 2.0 \mathrm{Ba}$ & $61.0 \pm 2.0 \mathrm{Aa}$ & $75.0 \pm 0.0 \mathrm{Aa}$ \\
\hline Ripe & $20.0 \pm 2.0 \mathrm{Bab}$ & $35.0 \pm 2.5 \mathrm{Bb}$ & $58.0 \pm 2.5 \mathrm{Aa}$ \\
\hline \multirow[t]{2}{*}{ Green } & $16.0 \pm 2.0 \mathrm{Bb}$ & $25.0 \pm 0.0 \mathrm{ABb}$ & $32.0 \pm 2.5 \mathrm{Ab}$ \\
\hline & \multicolumn{3}{|c|}{$3.0 \%$} \\
\hline Dried & $37.0 \pm 2.0 \mathrm{Ba}$ & $61.0 \pm 2.0 \mathrm{Aa}$ & $71.0 \pm 0.0 \mathrm{Aa}$ \\
\hline Ripe & $14.0 \pm 2.0 \mathrm{Cb}$ & $46.0 \pm 2.5 \mathrm{Bab}$ & $68.0 \pm 2.5 \mathrm{Aa}$ \\
\hline Green & $9.0 \pm 2.0 \mathrm{Bb}$ & $41.0 \pm 0.0 \mathrm{Ab}$ & $44.0 \pm 2.5 \mathrm{Ab}$ \\
\hline
\end{tabular}

Means followed by the same capital letters in the row and lowercase in column do not differ from each other at $5 \%$ of probability by the Tukey's test. The data were transformed into arc sine of $\sqrt{ }(\mathrm{x} / 100)$.

Los promedios seguidas por las mismas letras mayúsculas en la fila y minúsculas en la columna no difieren entre sí a 5\% de probabilidad por el test Tukey. Los datos se transformaron en arco seno de $\sqrt{ }(\mathrm{x} / 100)$.

the levels of essential amino acids were evaluated. Phorbol esters concentrations in varieties of seeds from Cape Verde, Nicaragua, and Nigeria were much higher than in the non-toxic Mexican seeds. Thus, the conclusion was that $J$. curcas toxicity is related to levels of phorbol ester in the plant.

Roach et al. (2012) developed a methodology to isolate phorbol esters of physic nut oil. According to these authors, by using such isolation methodology in the biodiesel industry of physic nut, phorbol esters could be obtained as co-products, which would make the plant more valuable. Devappa et al. (2012) tested phorbol esters extracted from J. curcas oil concerning its insecticidal activity against Spodoptera frugiperda (caterpillar in the third instar). Maize leaves treated with the substance were less consumed by the larvae. The caterpillars' relative growth and food conversion efficiency have been reduced 

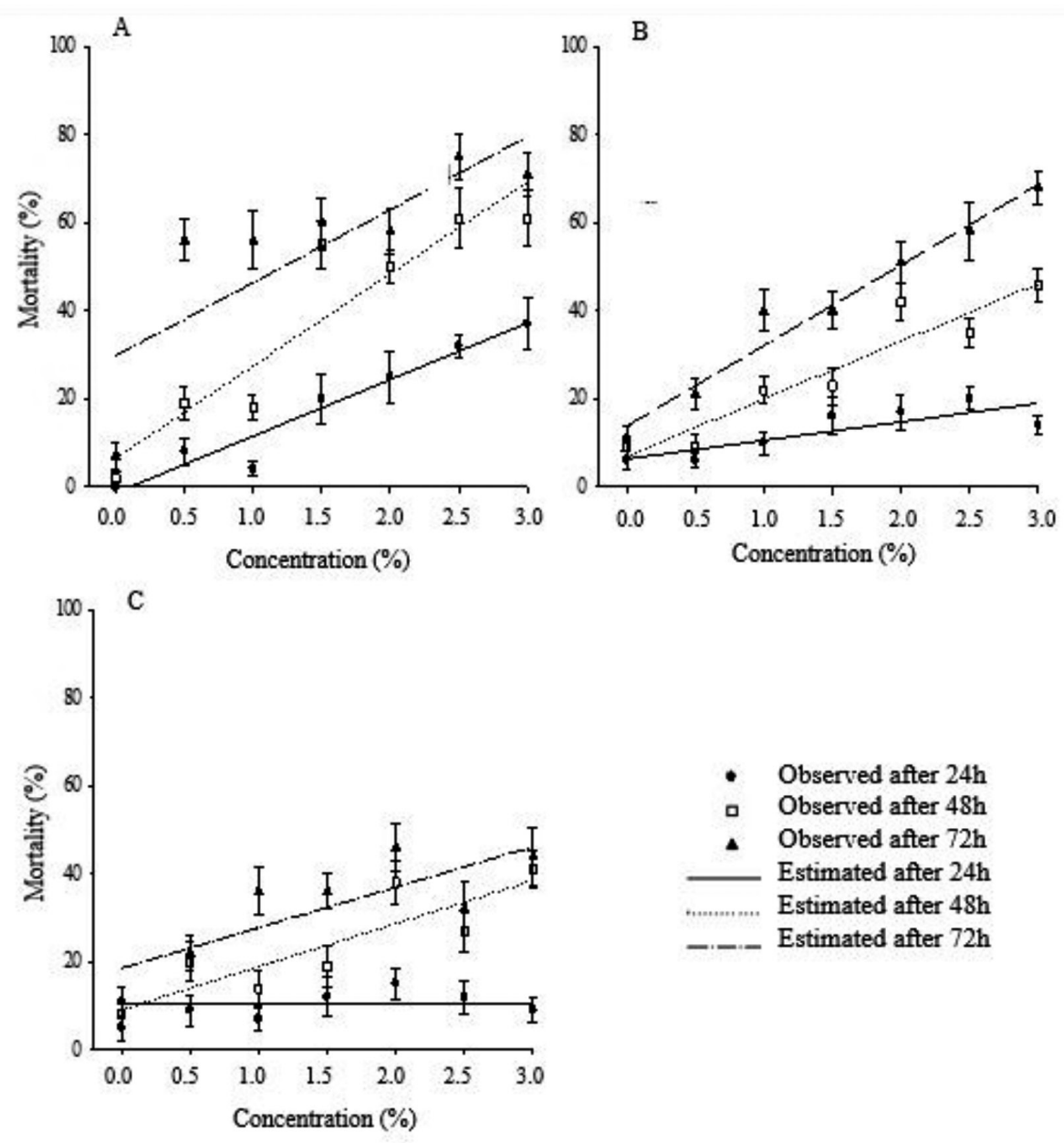

\begin{tabular}{cccc}
\hline & 24h & 48h & 72h \\
\hline Dried & $\mathrm{Y}=-1.28+12.85^{*} \mathrm{X}$ & $\mathrm{Y}=6.61+20.93^{*} \mathrm{X}$ & $\mathrm{Y}=29.85+16.57^{*} \mathrm{X}$ \\
& {$\left[\mathrm{R}^{2}=94.08 \%, \mathrm{P}=0.0003\right]$} & {$\left[\mathrm{R}^{2}=86.42 \%, \mathrm{P}=0.0024\right]$} & {$\left[\mathrm{R}^{2}=80.11 \%, \mathrm{P}=0.0304\right]$} \\
\hline Ripe & $\mathrm{Y}=6.39+4.21^{*} \mathrm{X}$ & $\mathrm{Y}=6.96+13.07^{*} \mathrm{X}$ & $\mathrm{Y}=13.85+18.28^{*} \mathrm{X}$ \\
& {$\left[\mathrm{R}^{2}=68.52 \%, \mathrm{P}=0.0215\right]$} & {$\left[\mathrm{R}^{2}=89.41 \%, \mathrm{P}=0.0013\right]$} & {$\left[\mathrm{R}^{2}=96.74 \%, \mathrm{P}=0.0001\right]$} \\
\hline Green & $\mathrm{Y}=10.43^{\mathrm{m}}$ & $\mathrm{Y}=9.17+9.78 * \mathrm{X}$ & $\mathrm{Y}=18.60+9.21^{*} \mathrm{X}$ \\
& & {$\left[\mathrm{R}^{2}=65.19 \%, \mathrm{P}=0.0281\right]$} & {$\left[\mathrm{R}^{2}=65.19 \%, \mathrm{P}=0.0281\right]$}
\end{tabular}

Figure 1. Mortality (\%) of Myzus persicae submitted to oil of seeds of dried (A) and ripe (B) fruits, and to green fruit (C) extract 24, 48 and 72 hours after spraying. Each symbol represents the mean of 10 replicates. Vertical bars indicate standard errors of the mean. The data of the regression analysis are presented on the table below the graphic.

to a phorbol ester concentration of $0.25 \mathrm{mg} \mathrm{mL}^{-1}$ $(w / v)$. Considering the fast growth of the biodiesel industry with J. curcas, according to the authors, large quantities of phorbol esters could be used in pest control. S. frugiperda caterpillars were more affected by higher concentrations of the bioactive compound (Devappa et al., 2012). Similarly, the increased mortality of cabbage aphids was directly proportional to the increased concentration of the tested extracts and oils.

In this study, we observed that the oil obtained from the J. curcas dried fruit caused higher mortality 
of the $M$. persicae population, especially in the first hours after the application, when we compare it to the oil of ripe fruit oil and to the green fruit extract, something that indicates that the first most likely had large quantity of toxic compounds. The oil of the ripe fruit was efficient against cabbage aphids but were necessary higher concentrations and an extended time to obtain similar results to the dried fruit oil.

The ripe fruit oil had the lowest efficiency regarding the insecticide action evaluated after 72 hours at the highest concentrations; so, it is probable that with an advanced stage of fruit maturation, an increase of the quantity of toxic compounds responsible for the cabbage aphid's mortality will take place. Gobbo-Neto y Lopes (2007) reported that the age and development of the plant and its diverse organs are important and can influence the total quantity of metabolites produced, and the relative proportion of the solution components. Thus, there may be differences in the quality and quantity of toxic compounds, such as the phorbol esters present in dried, ripe, and green fruits.

The hypothesis that the concentration of compounds -such as phorbol ester-varies according to the fruit maturation of $J$. curcas must be investigated in future works. The oil of J. curcas seeds is an attractive raw material for biodiesel production. The rapid increase of the commercial cultivation of this plant creates an opportunity of using its bioactive compounds as co-products for pest control.

\section{Conclusion}

Seeds of green, ripe, and dried fruits of $J$. curcas are toxic to cabbage aphids (M. persicae) and have the potential to be an alternative to control this pest. Concentration, time after application, and stage of fruit maturation influence the mortality of $M$. persicae, and the dried seed oil is more toxic than the others after the first hours of application.

\section{Acknowledgements}

We are grateful to "Instituto Federal do Espírito Santo" (IFES) for funding english translation and to Mrs. Mailyn Barros Cuevas for the spanish translation. Funding for this research was provided by "Conselho Nacional de Desenvolvimento Científico e Tecnológico" (CNPq), "Coordenação de Aperfeiçoamento de Pessoal de Nível Superior" (CAPES), "Empresa Brasileira de Pesquisa Agropecuária" (EMBRAPA) and "Fundação de Amparo à Pesquisa e Inovação do Espírito Santo" (FAPES).

\section{Literature Cited}

Adebowale, K.O.; Adedire, C.O.

2006. Chemical composition and insecticidal properties of the underutilized Jatropha curcas seed oil. Afr. J. Biotechnol., 5(10): 901-906.

Bashir, M.E.H.; Hubatsch I.; Leinenbach H.P.; Zeppezauer M.; Panzani R.C.; Hussein I.H.

1998. Ricin c 1 and Ricin c 3, the allergenic 2 S albumin storage proteins of ricinuscommunis: complete primary structures and phylogenetic relationship. Int. Arch. Allergy Immunol., 115: 73-82.

Brito, G.G. Costa, E.C.; Maziero, H.; Brito, A.B.; Dörr, F.A. 2004. Preferência da broca-das-cucurbitáceas [Diaphania nitidalis Cramer, 1782 (Lepidoptera: Pyralidae)] por cultivares de pepineiro em ambiente protegido. Ciênc. Rural, 34: 577-579.

Cardoso, M.G.; Shan, A.Y.K.V.; Souza, J.A 2001. Fitoquímica e química de produtos naturais. Editora UFLA, Lavras, Brazil. 67 p.

Cavalcanti, L.S. Cavalcanti, L.S.; DI Piero, R.M.; Cia, P.; Pascholati, S.F.; Resende, M.L.V.; Romeiro, R.S.

2005. Indução de resistência em plantas a patógenos e insetos. FEALQ, Piracicaba, Brazil. 263 p.
Darby, S.M.; Miller, M.L.; Allen, R.O.

2001. Forensic determination of ricin and the alkaloid marker ricinine from castor bean extracts. J. Forensic Sci., 46: 1033-1042.

Devappa, R.K.; Angulo-Escalante, M.A.; Makkara, H.P.S.; Beckera, K.

2012. Potential of using phorbol esters as an insecticide against Spodoptera frugiperda. Ind. Crop. Prod., 38: 50-53.

Ellis, P.R.; Singh, R.

1993. A review of the host plants of the cabbage aphid, Brevicoryne brassicae (Homoptera, Aphididae). IOBC/ WPRS Bulletin, 16: 192-201.

Ermel, K.; Pahlich, E.; Schmutterer, H.

1987. Azadirachtin content of neem kernels from different geographical locations, and its dependence on temperature, relative humidity, and light. In: Schmutterer, H.; Ascher, K.R.S. (Eds.) Natural pesticides from the neem tree and other tropical plants. Nairobi, Proceedings of the $3^{\circ}$ International Neem Conference. p. 171-184.

Gallo, D.; Nakano, O.; Silveira Neto, S.; Carvalho, R.P.L.; Baptista, G.C. De; Berti Filho, E.; Parra, J.R.P.; Zucchi, R.A.; Alves, S.B.; Vendramim, J.D.; Marchini, L.C.; Lopes, J.R.S.; Omoto, C. 
2002. Manual de Entomologia Agrícola. FEALQ, Piracicaba, Brazil. 920 p.

Gobbo-Neto, L.; Lopes, P.N.

2007. Plantas medicinais: fatores de influência no conteúdo de metabólitos secundários. Quím. Nova, 309(2): 374-381.

Gonzales, N.F.C.

2016. International experiences with the cultivation of Jatropha curcas for biodiesel production. Energy, 112: 1245-1258.

Gubitz, G.M.; Mittelbach, M.; Trabi, M.

1999. Exploitation of the tropical oil seed plant Jatropha curcas L. Bioresource Technol., 67: 73-82.

Haas, W.; Sterk, H.; Mittlebach, M.

2002. Novel 12-deoxy-16-hydroxyphorbol diesters isolated from the seed oil of Jatropha curcas. J. Nat. Prod., 65: 1434-1440.

Maghuly, F.; Laimer, M.

2013. Jatropha curcas, a biofuel crop: Functional genomics for understanding metabolic pathways and genetic improvement. Biotechnol. J., 8: 1172-1182.

Makkar, H.P.S.; Becker, K.; Schmook. B.

1998. Edible provenances of Jatropha curcas from Quintana Roo state of Mexico and effects of roasting on antinutrient and toxic factor in seeds. Plant Foods Hum. Nutr., 52: 31-36.

Roach, J.S. Roach J.S.; Devappa, R.K.; Makkar, H.P.; Becker, K. 2012. Isolation, stability and bioactivity of Jatropha curcas phorbol esters. Fitoterapia, 83: 586-592.

Roy, S.; Handique, G.; Barua, A.; Bora, F.R., Rahman, A.; Muraleedharan, N.

2018. Comparative performances of jatropha oil and garlic oil whit synthetic acaricides against red spider mite infesting tea. P. Natl. A. Sci. India B, 88(1): 85-91.
Sabandar, C.W.; Ahmat, N.; Jaafar, F.M.; Sahidin, I.

2013. Medicinal property, phytochemistry and pharmacology of several Jatropha species (Euphorbiaceae): A review. Phytochemistry 85: 7-29.

Schoonhoven, L.M.; Loon, J.J.A.; Dicke, M. 2005. Insect-plant biology. Oxford University Press, New York, USA. 421 p.

Selase, A.G.; Getu, E.

2009. Evaluation of botanical plants powders against Zabrotes subfasciatus (Boheman) (Coleoptera: Bruchidae) in stored haricot beans under laboratory condition. Afr. J. Agric. Res., 4(10): 1073-1079.

Silva, G.N., Faroni, L.R.A.; Sousa, A.H.; Freitas, R.S.

2012. Bioactivity of Jatropha curcas L. to insect pests of stored products. J. Stored Prod. Res., 48: 111-113.

Sousa, A.H.; Faroni, L.R.D.; Silva, G.N.; Freitas, R.S.

2009. Toxicidade de pós e extratos aquosos de sementes e pericarpos de Pinhão manso (Jatropha curcas 1.) sobre insetos-praga de produtos armazenados. In: I Congresso Brasileiro de Pesquisas de Pinhão Manso, Brasília. Anais, Embrapa Agroenergia. CD-ROM.

Stirpe, F.; Pession-Brizzi, A.; Lorenzoni, E.; Strocchi, P.; Montanaro, L.; Sperti, S.

1976. Studies on the proteins from the seeds of Croton tigliumi and of Jatropha curcas. Toxic properties and inhibition of protein synthesis in vitro. Biochem. J., 156: 1-6.

Ukpai, O.M.; Ibediungha, B.N.; Ehisiania, C.N. 2017. Potencial of seed of Jatropha curcas L., Thevetia peruviana (PERS.) and Piper guineense SCHUMACH. against the maize weevil Sitophilus zeamais (MOTSCHULSKY, 1855) (Coleoptera: Curculionidae) in storage of corn grain. Pol. J. Entomol., 86: 237-250. 
